\title{
EFFICIENCY INVESTIGATION OF THE USE OF PYROPHYLLITE IN ENSILING MAIZE PLANT
}

Milan J. Adamović ${ }^{1}$, Mirjana D. Stojanović ${ }^{2}$ Muhamed M. Harbinja ${ }^{3}$, Marijana D. Maslovarić ${ }^{4}$, Aleksandra S. Bočarov-Stančić ${ }^{*}$, Lato L. Pezo ${ }^{5}$

${ }^{1}$ Institute for Technology of Nuclear and Other Mineral Raw Materials, 11000 Belgrade, Bul. Franše d'Eperea 86, Serbia

${ }^{2}$ Engineering Academy of Serbia, 11000 Belgrade, Kneza Miloša 9/I, Serbia

${ }^{3}$ AD Harbi Ltd., 71000 Sarajevo/Ilidža, Tvornička 3, Federation of Bosnia and Herzegovina (BiH)

${ }^{4}$ Institute for Science Application in Agriculture, 11000 Belgrade, Bul. despota Stefana 68b, Serbia

${ }^{5}$ University of Belgrade, Institute of General and Physical Chemistry, Studentski trg 12/V, 11000 Belgrade, Serbia

\begin{abstract}
The paper presents the results of testing the effect of pyrophyllite shale (pyrophyllite) on the quality of maize plant silage, primarily on the production of organic acids, $\mathrm{pH}$ value, quality assessment and microbiological safety. The ensiling was done in plastic containers which allowed the storage of $10 \mathrm{~kg}$ of chopped green mass. Tested pyrophyllite doses were: $0 \%$ in the control treatment (I), 0.5 and $1.0 \%$ in experimental treatments (II and III, respectively). Granulated pyrophyllite $(100 \mu \mathrm{m})$, originating from Parsovići, Konjic site, AD Harbi Ltd., Sarajevo, Bosnia and Herzegovina, was manually incorporated. The chopped green mass of the maize plant came from FAO 600 hybrids. The green mass containing $37.17 \%$ of dry matter (final waxy ripening phase) was compressed in the same manner in all three treatments during the filling of the vessels. The containers were then covered with nylon foil $(0.2 \mathrm{~mm})$ above which a layer of fine sand (approx. $5 \mathrm{~cm}$ ) was placed in toward the silage protection from air passage. The silages were opened after 7 weeks and organoleptic, chemical and microbiological analyses were performed. The organoleptic properties of silages (colour and odour) were better in silages containing 0.5 and $1.0 \%$ pyrophyllite. The silage temperature at the moment of opening of the containers was lower in the treatments with 0.5 and $1.0 \%$ added pyrophyllite $\left(13.7\right.$ and $13.2{ }^{\circ} \mathrm{C}$, respectively) while in the control treatment it was $14.6^{\circ} \mathrm{C}$. The addition of pyrophyllite to silage affected the production of volatile fatty acids $(\mathrm{p} \leq 0.05)$. The highest amount of lactic acid was found in the silage sample without the addition of pyrophyllite, and acetic acid in the silage treated with 0.5 and $1.0 \%$ of pyrophyllite. The lowest amount of butyric acid was determined in the silage with the addition of $1 \%$ pyrophyllite. Based on the content and interrelationship of lactic, acetic and butyric acid, as well as the $\mathrm{pH}$ values, all three silages were rated as the highest (I) class. The number of aerobic mesophilic bacteria, as well as the number of yeasts, was lower in the silages with the addition of 0.5 and $1.0 \%$ pyrophyllite. In future, particular attention should be paid on the possibility of pyrophyllite enrichment (e.g. with nitrogen) and more appropriate physical formulation (e.g. granules) that would allow more efficient practical application.
\end{abstract}

Keywords: ensiling, maize plant, pyrophyllite 


\section{INTRODUCTION}

Ensiling is the complex biotechnological process, thanks to which preserved green bulky fodder (alfalfa, meadow grasses, green corn, etc.) can be stored for a long time, during a one year and for many years. The process is based mainly on the activities of lactic acid bacteria that, in the absence of air in the ensiled mass during fermentation, use carbohydrates and produce lactic acid, which is a natural preservative (Adamović, Stoićević \& Jovanović, 1997). Due to the formation of lactic acid, $\mathrm{pH}$ in the ensiled mass decreases to 3.8. If silage is not well prepared it is usually too acidic and represents a favourable environment for the development of moulds. Therefore mycotoxins may occur as well as high nutrient losses and such silage is not recommended for animal nutrition. In order to improve the silage quality, carbohydrate additives (cornmeal, molasses, sugar beet noodles, steamed or dehydrated whey), bacterial enzyme inoculants and mineral additives are often added during the ensiling process, depending on the type of ensiled material. There is the evidence that the addition of mineral substances (bentonite or zeolite) to the silage mass promotes the fermentation and production of certain organic acids, thereby contributing to easier maintenance of the desired $\mathrm{pH}$ level in silage reducing the risk of deterioration. This is especially important because the losses, due to the spoilage of silage, can be extremely high.

Depending on the quality of the ensiling process carried out and the silage holding facilities, they can range up to $5-20 \%$ and in some cases such as silage placed next to silo walls or in the upper silo layers up to $75.8 \%$ (Ashbell \& Kashanchi, 1987). It should be pointed out that some of the minerals of alumosilicate origin (zeolite, bentonite) are in some properties similar to pyrophyllite shale (pyrophyllite) and have the ability to adsorb mycotoxins and heavy metals, as well as to inhibit the development of some microorganisms, which is of particular importance in the process of safe food production. In the absence of papers dealing with the effect of pyrophyllite on the quality of silage, this paper cites other papers related to the mineral zeolite and a lesser extent those dealing with bentonite. Studies of Adamović, Sinovec, Nešić and Tomašević Čanović (2001) revealed that under standard conditions of a maize plant ensiling, the addition of $0.2 \%$ modified zeolitebased preparation (Mina-Zel Plus) resulted in the increase in lactic acid content from 73.36 to $82.20 \%$, and the decrease in the acetic acid content from 26.64 to $17.8 \%$, with a slight increase in $\mathrm{pH}$ from 3.33 to 3.35 . The total number of molds was significantly lower in this silage. The presence of mycotoxins in these silages was not detected or they were present in trace amounts. The silages were rated as class I (49 points). Contrary to that, under partially appropriate ensiling conditions, the addition of Mina-Zel Plus resulted in the significant increase in the amount of lactic acid from 49.52 to $75.40 \%$, and the decrease in the amount of acetic acid from 50.48 to $24.61 \%$. Also, $\mathrm{pH}$ increased from 3.36 to 3.40 . The total number of molds in silage with this supplement was significantly lower, as well as the concentration of mycotoxins (zearalenone, T-2 toxin and diacetoxyscirpenol-DAS). Silage without tested mentioned supplement (MinaZel Plus) was rated as class II (37 points) and with its addition as class I (49 points). These results indicate the actuality of the investigated silage preparation since silages meet most of the dry matter needs (50-70\%) in cattle rations.

Similar positive effects of zeolite or zeolitebased preparations with urea on the quality of silage were achieved in the studies of Đorđević, Adamović, Grubić \& BočarovStančić (2004), Đorđević, Grubić \& Adamović (2005), Đorđević, Grubić. Adamović, Nježić \& Stojanović (2006), and Koljajić, Đorđević, Grubić \& Adamović (2003). Adamović (2001) found that the addition of $\mathrm{Ca}$ - or Na-bentonite to the grasses green mass had the effect of increasing the production of total acids, especially lactic acid and increasing the $\mathrm{pH}$ value, by $\mathrm{Ca}$-bentonite giving more favourable results. Na-bentonite resulted in higher $\mathrm{CO}_{2}$ production and increased dry matter losses. The authors concluded that the use of zeolite and bentonite-based preparations in ensiling technology has its justification and significance, especially in hampered working conditions, increased material moisture, presence of moulds and toxins in green mass, ensiling discontinuity, insufficient trampling and inadequate protection of silage in the silo. Such and similar preparations, especially in com- 
bination with other additives (bacterial-enzymatic inoculants, urea and others), can give complementary and synergistic effects.

The positive results of testing zeolites and bentonites, as well as other minerals in the ensiling process, are a good basis and recommendation for new researches in the field of silage mineral additives, in this particular case pyrophyllite.

In terms of better understanding pyrophyllite, its characteristics, possibilities of modification and application in the industry, there are several papers among which are papers from the following authors: Keren \& Sparks (1994), Sanchez-Soto, Justo \& Pérez-Rodríguez (1994), Erdemoglu, et al. (2004), Drits, Derkowski \& McCarty (2011), Kim, Lee, Park \& Kang (2013), Park, Kim, Lee \& Kim (2013), Essalhi, Essalhi, Toummite, Mostadi \& Raddi (2017), Harbinja et al. (2018), Desai, Biswal \& Paria (2010) and others.

Pyrophyllite is a monoclinic mineral of the phyllosilicate group, with the chemical formula $\mathrm{Al}_{2}\left[\mathrm{Si}_{4} \mathrm{O}_{10}\right](\mathrm{OH})_{2}$. It arose by a hydrothermal metamorphosis of the underground lava which, by the interaction with groundwater, steam and pressure, turned into clay. It got its name from the Greek pyro-fire and phillon-leaf because when annealed, it turns to be fanlike. Depending on the oxide content, the colour varies and ranges from white, greywhite, purple-white, to greyish-greenish. The Mohs hardness is $1-1.5$ and pyrophyllite has the buttery touch like talc. It is rich in silicon and aluminium and for that reason; it belongs to the group of non-metallic aluminosilicate minerals.

Pyrophyllite has a neutral electromagnetic charge and its $\mathrm{pH}$ is between 7.5 and 8.5. The specific gravity of pyrophyllite is 2.7-2.9 $\mathrm{g} / \mathrm{cm}^{3}$. The moisture content of $0.25 \mathrm{~mm}$ granulation sample dried at $105^{\circ} \mathrm{C}$ is $0.26 \%$.

It contains electrolytes (sodium, potassium, calcium, magnesium, iron, etc.) and free ions that give it the ability to be detoxicant and antioxidant. Ions transport toxins from cells and vice versa nutrients into the cell. Hydroxyl groups $(-\mathrm{OH})$ are bound to the inner layer of the three-layer crystal lattice making pyrophyllite poorly reactive. The three-layer lattice consists of two layers of tetrahedrons between which one layer of octahedrons $(2: 1$ or $\mathrm{T}-\mathrm{O}-\mathrm{T}$ the type of structure) is placed. It is insoluble (hydrophobic) in water and does not swell.

The following minerals prevail in pyrophyllite shale: pyrophyllite, sericite and kaolinite, and to a lesser extent, it also contains quartz, calcite, magnesite, dolomite, illite and montmorillonite. As adsorption and absorption clay with a combination of ring-shaped tetrahedral molecules, it resembles the shape of red blood cells, representing the most appropriate geometric shape for the uptake and/or delivery of nutrients.

In the field of animal husbandry, besides adsorptive and absorptive capacity, pyrophyllite and similar alumosilicate materials (bentonite and zeolite) have properties of preventing feed mixtures to become lumpy, increasing the degree of their homogenization and the quality of pelleted feedstuffs, reducing the degree of friction and wear out of pellet press. It has also excellent ability to prevent and repair acidosis in ruminants' rumen, especially of dairy cows and beef cattle in intensive fattening (Adamović et al., 2001; Adamović et al., 2004.; Erdemoglu et al., 2004; Vujanac, Adamović, Šamanc, Petrujkić \& Dimitrijević, 2005; Drits, Derkowski \& McCarty, 2011; Adamović, 2019; Adamović \& Stojanović, 2019; Harbinja et al., 2019). These are also the reasons why the United States Food and Drug Administration (2019) allowed the use of pyrophyllite in animal feed in the quantity up to $2 \%$.

The implemented study aimed to determine the effect of pyrophyllite on the quality of silage fermentation, first of all, the production of organic acids (lactic, acetic and butyric), then on the $\mathrm{pH}$ value, quality assessment and microbiological safety of silage.

\section{MATERIALS AND METHODS}

The ensiling of a maize plant green mass was done in plastic containers whose volume (13 $\mathrm{dm}^{3}$ ) provides placing of $10 \mathrm{~kg}$ of green mass. In laboratory silos, $0.769 \mathrm{~kg} / \mathrm{dm}^{3}$ green mass was placed for each treatment (control-I, and pyrophyllite-II and III). Doses of pyrophyllite added to silage were 0 at the control treatment, and 0.5 and $1.0 \%$ at the two experimental treatments. The pyrophyllite granulation (100 $\mu \mathrm{m})$ was manually incorporated and originated from the Parsovići, Konjic site, AD Harbi Ltd., Sarajevo, Bosnia and Herzegovina. The tested pyrophyllite contained $64.15 \% \quad \mathrm{SiO}_{2}, 15.10 \%$ 
$\mathrm{Al}_{2} \mathrm{O}_{3}, 1.57 \% \mathrm{Fe}_{2} \mathrm{O}, 6.65 \% \mathrm{CaO}, 1.06 \% \mathrm{MgO}$, with low oxide content of $\mathrm{Na}, \mathrm{K}, \mathrm{Ti}, \mathrm{Fe}, \mathrm{P}, \mathrm{S}$ and $\mathrm{Ba}$ (below 1\%).

The chopped green mass of the maize plant came from one of the FAO 600 hybrids, collected from one of the parcels of the Padinska Skela farm, in the ALDAHRA business system. The green mass contained $37.17 \%$ of dry matter and was in the final stage of waxy ripening. The reasons for the unusually high dry matter content are the extremely high temperatures and the fast drying of the plants before ensiling.

During the filling of the vessels in the control and experimental treatments, the green mass was compressed under identical conditions to push out air. After filling, the vessels were covered with nylon foil $(0.2 \mathrm{~mm})$ above which a layer of sand (approx. $5 \mathrm{~cm}$ ) was placed in order to protect the foil from damage and the passage of air. Ensiling was done in one replicate per control and experimental treatments (Figure 1). In this way, the practical silage conditions on farms in horizontal trench silos were simulated.

The silages were stored in a storage room adequate for storing fodder (protected from moisture, high temperature, and excessive sunlight). The ensiling was performed on 15.08.2019, and the silage was opened 7 weeks after the ensiling (08.10.2019).

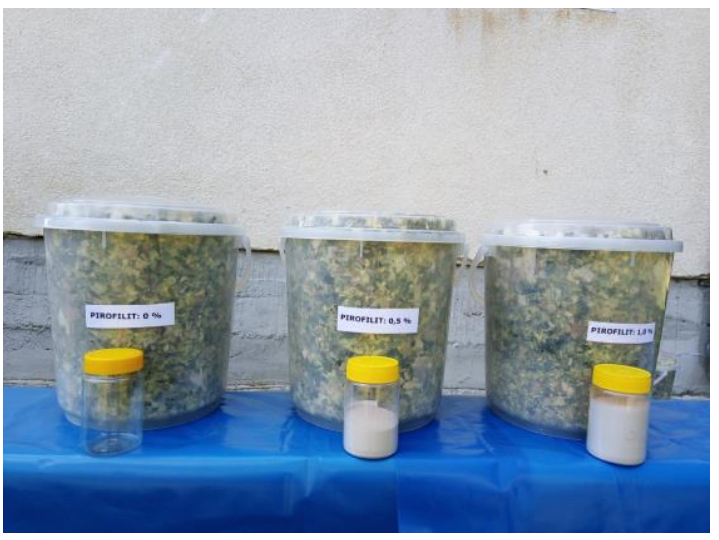

Figure 1. Green mass of chopped corn plant in plastic containers

Organoleptic characteristics of silages (colour, odour and structure) were analysed. Silage extracts were prepared for chemical analysis according to the procedure described by Đorđević et al. (2003). Analysed chemical characteristics of silages were: dry matter and pH (Pravilnik, 1987), lactic acid, acetic acid, butyric acid according to Eko Lab, accredited method EL15305 005-04 (Obradović, 1965). Based on the results of these analyses silage quality-points and class were determined. Microbiological analysis of silages was done according to following standards: SRPS EN ISO 4833-1:2014 (colony forming units CFU), SRPS EN ISO 6888-1:2009 (Staphylococcus aureus and other Staphylococcus species), SRPS EN ISO 7937:2010 (Clostridium perfringens), SRPS EN ISO 65791:2017 (Salmonella spp.) and SRPS ISO 21527-2:2011 (determination of yeasts and moulds). Silage temperature was measured on an opening day. The quality of the silage was determined using DLG procedure - Deutsche Landwirtschafts-Geselschaft method, as described by Bakici \& Demirel (2004) and Marković et al. (2018). All analyses were done in triplicates.

Statistical analysis of variance and Tukey's HSD test at $95 \%$ confidence were used.

\section{RESULTS AND DISCUSSION}

\section{Silage quality}

The basic parameters of silage quality assessment are organoleptic and chemical properties.

\section{Organoleptic properties of silages}

Determined organoleptic characteristics were odour, colour and structure. In their assessment, the temperature of the silage at the moment of the opening was also recorded, since it can have some influence on the colour of the silage during fermentation, as well as on the preservation of nutrients. The colour of the silage varied in mild shades. While silage without pyrophyllite had a slightly darker yellow colour and to a lesser extent brown, silage with added pyrophyllite had a paler yellow colour, wherein silage with $1.0 \%$ pyrophyllite had a slightly noticeable lighter yellow-green colour shade (Figure 2). These differences in colour shades can, in a certain way, be related to the determined temperature in the silage at the moment of opening. The darker colour of the silage without the addition of pyrophyllite, and partly with the one with $0.5 \%$ pyrophyllite, is probably due to the increased temperatures during the aerobic fermentation phase, which could have affected the colour and therefore the biological value of nutrients (primarily proteins) in such silages (Adamović \& Obradović, 2016). If during the 
Table 1.

Organoleptic characteristics of silages

\begin{tabular}{|c|c|c|c|}
\hline Parameter & $\begin{array}{c}\text { I } \\
\text { Without } \\
\text { pyrophyllite }\end{array}$ & $\begin{array}{c}\text { II } \\
\text { Pyrophyllite } \\
0.5 \%\end{array}$ & $\begin{array}{c}\text { III } \\
\text { Pyrophyllite } \\
1.0 \%\end{array}$ \\
\hline Colour & Mildly brown-yellow & Yellow & Yellow-green \\
\hline Odour & $\begin{array}{c}\text { Less pronounced } \\
\text { characteristic silage } \\
\text { odour }\end{array}$ & $\begin{array}{c}\text { More pronounced } \\
\text { characteristic silage } \\
\text { odour }\end{array}$ & $\begin{array}{c}\text { Most pronounced } \\
\text { characteristic silage } \\
\text { odour }\end{array}$ \\
\hline Structure & $\begin{array}{c}\text { Clearly visible cuts } \\
\text { dominate } \\
(0.5-1.0 \mathrm{~cm})\end{array}$ & $\begin{array}{c}\text { Clearly visible cuts } \\
\text { dominate } \\
(0.5-1.0 \mathrm{~cm})\end{array}$ & $\begin{array}{c}\text { Clearly visible cuts } \\
\text { dominate } \\
(0.5-1.0 \mathrm{~cm})\end{array}$ \\
\hline $\begin{array}{l}\text { Silage temp. on the } \\
\text { opening day }\left({ }^{\circ} \mathrm{C}\right)\end{array}$ & 14.6 & 13.7 & 13.2 \\
\hline
\end{tabular}

aerobic fermentation phase, the temperature in the silage mass reaches $50{ }^{\circ} \mathrm{C}$ or more, Maillard reaction (binding of amino groups of amino acids to sugars) may occur, which results in a decrease in the digestibility of the proteins in such silages (Muck et al., 2003). At the time of silages opening, the temperature was $14.6,13.7$ and $13.2{ }^{\circ} \mathrm{C}$, respectively. The lower temperature in silages with added pyrophyllite at the moment of opening can be related to their ability to bind heat and release it under certain conditions.

The odour of silages was only slightly different. In the silage, without added pyrophyllite, the characteristic silage odour was less pronounced, while in the silage with added pyrophyllite the characteristic odour was more pronounced, especially in the silage with $1.0 \%$ pyrophyllite. These two characteristics (colour and odour especially), although subjectively judged, may be relevant to the animals' willingness to consume the offered silage, which should be proven in biological experiments with animals (cows, beef cattle or sheep).

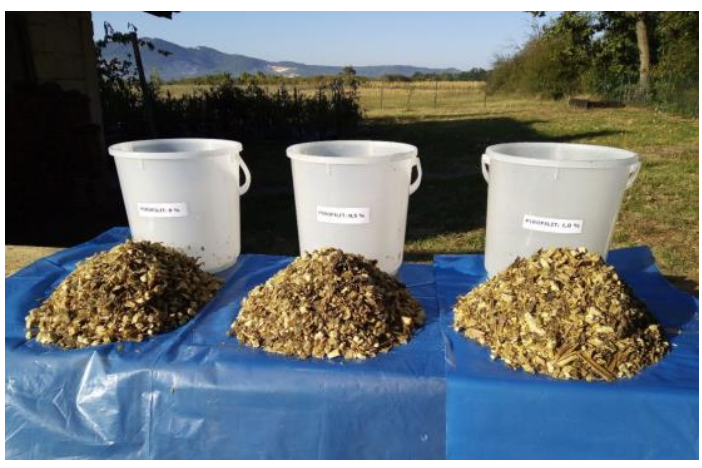

Figure 2. Corn plant silages 7 weeks after ensiling

The structure of all three analysed silages was identical and clearly expressed as the sections of the optimum corn stems length (0.5 to 1.5 $\mathrm{cm})$, with the visible presence of leaf and whole or partially broken corn grains. There is not enough qualitative data in the available literature on the influence of pyrophyllite on organoleptic properties of silages.

\section{Chemical characteristics of silages}

Important data as dry matter content, $\mathrm{pH}$ value and volatile fatty acid content of silages are presented in Table 2.

Dry matter content of the silage was characteristic for maize silage in the final stage of waxy ripening. It is observed that, when treated with $1.0 \%$ pyrophyllite, dry matter content was significantly higher than in the case of the other two treatments (control and $0.5 \%$ pyrophyllite). The reason for such an increase in dry matter content was the amount of dry matter introduced through pyrophyllite. This circumstance should not be considered a handicap, but more an advantage for the use of pyrophyllite in silage with a lower dry matter content in ensiled mass (below 28\%). In all three treatments, the $\mathrm{pH}$ values were very uniform and within the optimum values (3.84.2) for maize silage, thus creating favourable conditions for the prevention of microorganism activity and its deterioration.

The addition of pyrophyllite to silage affected the production of volatile fatty acids $(\mathrm{p} \leq$ 0.05 ). The highest amount of lactic acid was found in silage without the addition of pyrophyllite, and acetic acid in silage with 0.5 and $1.0 \%$ of pyrophyllite. The lowest amount of butyric acid was determined in silage with the addition of $1 \%$ pyrophyllite.

However, despite that, on the base of lactic acid content, all three silages got maximum marks (10 points). In contrast to that, the free acetic acid, as well as total acetic acid content was higher in silages with added pyrophyllite, 
Table 2.

Dry matter content, $\mathrm{pH}$ and volatile fatty acids in the silages

\begin{tabular}{lccc}
\hline Indicator & $\begin{array}{c}\text { I } \\
\text { Without } \\
\text { pyrophyllite }\end{array}$ & $\begin{array}{c}\text { II } \\
\text { Pyrophyllite } \\
\mathbf{0 . 5 \%}\end{array}$ & $\begin{array}{c}\text { III } \\
\text { Pyrophyllite } \\
\mathbf{1 . 0 \%}\end{array}$ \\
\hline Dry matter (\%) & $35.98 \pm 0.24^{\mathrm{b}}$ & $35.21 \pm 0.12^{\mathrm{a}}$ & $37.26 \pm 0.21^{\mathrm{c}}$ \\
$\mathrm{pH}$ & 4.00 & 3.99 & 3.96 \\
Lactic acid (\%) & $69.92 \pm 0.20^{\mathrm{c}}$ & $64.75 \pm 0.22^{\mathrm{a}}$ & $65.38 \pm 0.20^{\mathrm{b}}$ \\
Free acetic acid (\%) & $23.81 \pm 0.26^{\mathrm{a}}$ & $29.73 \pm 0.27^{\mathrm{b}}$ & $29.72 \pm 0.24^{\mathrm{b}}$ \\
Bound acetic acid (\%) & $5.55 \pm 0.16^{\mathrm{b}}$ & $5.52 \pm 0.18^{\mathrm{b}}$ & $3.04 \pm 0.20^{\mathrm{a}}$ \\
Free butyric acid (\%) & $\mathrm{ND}$ & $\mathrm{ND}$ & ND \\
Bound butyric acid,\% & 0.72 & $\mathrm{ND}$ & 1.86 \\
Total acidity (g/100 g sample) & $2.21 \pm 0.21^{\mathrm{a}}$ & $2.16 \pm 0.14^{\mathrm{a}}$ & $2.05 \pm 0.22^{\mathrm{a}}$ \\
Silage quality (DLG method) & & & 48 \\
Points & 49 & 48 & $\mathrm{I}$ \\
Class & $\mathrm{I}$ & $\mathrm{I}$ & \\
\hline
\end{tabular}

Not detected (ND)

Means in the same row with different superscript are statistically different $(p \leq 0.05)$

but within the optimum values for this type of silage. DLG method does not include the determination of the presence of propionic acid in silage and so it was not determined. In all three tested silages, the low content of butyric acid was determined. Based on the sum of the points on all bases, all three silages were categorized as the highest class (I).

Currently, there is not enough qualitative data in the available literature on the influence of pyrophyllite on fermentation in silage. Similar results for lactic acid $(>60 \%)$, acetic acid $(<30 \%)$ and butyric $(<1 \%)$ acid and class were determined by Đorđevic et al. (2004), Đorđević et al. (2006), Adamović, Milivojčević, Živanović, Bočarov-Stančić and Šorić (2015), Adamović and Obradović (2016), in corn silage with similar dry matter content $(>30 \%)$.

It should be noted that a very high amount of lactic acid in silage without the addition of pyrophyllite can, in certain circumstances, be a handicap because it has a weaker fungicidal effect, i.e. the ability to prevent the development of aerobic microorganisms (yeasts and moulds) in silage. Additionaly, if such silage is used in large quantities in cattle rations, it can contribute to the acidification of the rumen's content ( $\mathrm{pH}$ disturbance), which in turn leads to worse conditions for the activity of beneficial ruminant microorganisms, lower efficiency of digestion and utilization of feed, decrease in milk fat content, hoofs disease and other health disorders (Grubić \& Adamović, 2003). On the other hand, slightly increased acetic acid content, as determined in silages with the addition of 0.5 and $1.0 \%$ pyrophyllite, can also be a favourable circumstance since it inhibits the development of harmful aerobic microorganisms in silage, thus contributing to its aerobic stability. The importance of maintaining the aerobic stability of silage is referred by numerous papers, among which are the works of Ashbell, Weinberg, Hen \& Filya (2002), Danner, Holzer, Mayrhuber \& Braun (2003), Borreani et al. (2007), Acosta (2008), Pahlow \& Muck (2009), Borreani \& Tabacco (2010), Ivetić et al. (2013) and others.

In subsequent similar studies appropriate attention must be paid on these details, in which, among other things, it would be useful to investigate how the characteristics and quality of silage fermentation are affected by higher doses of pyrophyllite, e.g. between 1.0 and $2.0 \%$ of the amount of green mass input that is being ensiled. Analysis of variance and Tukey's HSD test at 95\% confidence limit, showed significant differences between the observed samples.

Considering that pyrophyllite, among other things, the ability to adsorb mycotoxins in ruminants' rumen (primarily aflatoxins) (Bočarov-Stančić et al., 2015) and heavy elements (Karnwal \& Bhardway, 2014), as well as to maintain optimum $\mathrm{pH}$ in the rumen, further study on the justifiability for the use of pyrophyllite in silage or haylage of any kind, as well as in the composition of feed-stuffs, has its justification and economic importance. Of course, in this context, particular attention should be paid to the possibility of its enrichment (e.g. with nitrogen) and more appropriate physical formulation of pyrophyllite (e.g. granules) that allow more efficient application in practical conditions. 
Table 3.

Microbiological analysis of silages

\begin{tabular}{lccc}
\hline Indicator & $\begin{array}{c}\text { I } \\
\text { Without } \\
\text { pyrophyllite }\end{array}$ & $\begin{array}{c}\text { II } \\
\text { Pyrophyllite } \\
\mathbf{0 . 5 \%}\end{array}$ & $\begin{array}{c}\text { III } \\
\text { Pyrophyllite } \\
\mathbf{1 . 0 \%}\end{array}$ \\
\hline Salmonella spp. (in 50 g) & $\mathrm{ND}$ & $\mathrm{ND}$ & ND \\
Staphylococcus aureus (CFU/g) & $<10$ & $<10$ & $<10$ \\
Clostridium perfringens (CFU/g) & $<10$ & $<10$ & $<10$ \\
Clostridium spp. (CFU/g) & $<10$ & $<10$ & $<10$ \\
Aerobic mesophilic bacteria (CFU/g) & $5.0 \times 10^{6}$ & $3.7 \times 10^{6}$ & $3.9 \times 10^{6}$ \\
Yeasts (CFU/g) & $1.3 \times 10^{5}$ & $1.1 \times 10^{5}$ & $0.69 \times 10^{5}$ \\
Moulds (CFU/g) & $<100$ & $<100$ & $<100$ \\
\hline
\end{tabular}

Not detected $(N D)$

\section{Microbiological analysis of silages}

The presence of Salmonella spp. (Table 3) was not detected in the tested silages. The presence of pathogenic bacteria Staphylococcus aureus, Clostridium perfringens and Clostridium spp. were $<10 \mathrm{CFU} / \mathrm{g}$ (CFU-colony forming units) that is below the detection limit for the quantitative determination of bacteria in solid feedstuffs.

The presence of aerobic mesophilic bacteria in silage without the addition of pyrophyllite was $5 \times 10^{6} \mathrm{CFU} / \mathrm{g}$, while in silages with the addition of pyrophyllite $(0.5 \%$ and $1.0 \%$, respectively) it was visibly lower and amounted $3.7 \times 10^{6}$ and $3.9 \times 10^{6} \mathrm{CFU} / \mathrm{g}$, respectively, but did not decrease with the increasing pyrophyllite dose from $0.5 \%$ to $1.0 \%$.

Aerobic mesophilic bacteria, as their name implies, are those that divide and are active at the temperature range from 20 to $45^{\circ} \mathrm{C}$ in the presence of oxygen. Obviously, a slightly higher temperature in silage without pyrophyllite $\left(14.6{ }^{\circ} \mathrm{C}\right)$ was the more suitable environment for their development, unlike to silages with $0.5 \%$ and $1.0 \%$ pyrophyllite, in which the lower temperature was measured (13.7 and $13.3{ }^{\circ} \mathrm{C}$, respectively) and therefore less favourable conditions for their division and activity were present. The presence of yeasts was distinctly higher in silage without the pyrophyllite addition and decreased with the increase of pyrophyllite dose from 0.5 to $1.0 \%$, and it was $1.3 \times 10^{5}, 1.1 \times 10^{5}$ and $0.69 \times 10^{5} \mathrm{CFU} / \mathrm{g}$, respectively. Yeast activity in silage increases temperature consumes the energy of silage (sugars) and reduces the efficiency of its use. Additionally, they change the smell and taste of silage, which affects their consumption. The presence of the higher number of yeast in silage without the addition of pyrophyllite can be directly related to its inferior organoleptic properties and the established temperature at the time of opening that was confirmed in this study. The presence of moulds in all three tested silage samples was $<100 \mathrm{CFU} / \mathrm{g}$ (Table 3). The presence of mycotoxins was not analyzed due to the small number of molds. Losses in silage due to its spoilage (mould infestation - spoiled silage) on the surface layer, under the cover foil, could not be estimated accurately enough. The impression is that the thickness of the visually altered surface layer on the pyrophyllite added silages was smaller.

\section{CONCLUSIONS}

The addition of pyrophyllite to the chopped corn green mass in the amount of 0.5 and $1 \%$ of the input mass had the favourable effect on the most important organoleptic properties (colour and odour of silage). At the time of opening silage, the temperature was lower in silages with the addition of pyrophyllite by 0.9 and $1.4{ }^{\circ} \mathrm{C}$, respectively.

The addition of pyrophyllite to silage affected the production of volatile fatty acids $(\mathrm{p} \leq$ $0.05)$. The highest amount of lactic acid was found in silage without the addition of pyrophyllite, and acetic acid in silage with 0.5 and $1.0 \%$ of pyrophyllite. The least butyric acid was determined in silage with the addition of $1 \%$ pyrophyllite. All three silages were rated as I class. The addition of pyrophyllite reduced the number of aerobic mesophilic bacteria and yeasts.

Results of the present research can be considered as preliminary since there has been no data on this particular matter in the available literature, to the best of our knowledge. The future research should be focused on confirmation of these results with a greater number of repetitions. Furthermore, 
particular attention should be paid to the possibility of pyrophyllite enrichment (e.g. with nitrogen) and its more appropriate physical form (e.g. granules) that allows the more efficient application of pyrophyllite in practical conditions.

\section{ACKNOWLEDGEMENTS}

The testing was carried out within the research program "Pyrophyllite based product research and development program in animal husbandry and veterinary medicine", supported by $A D$ Harbi Ltd. Sarajevo, Federacija BiH, and was also the result of undertaken investigations within the contract on the implementation and financing of scientific researches in 2020 between the Institute for Science Application in Agriculture, Belgrade and the Ministry of Education, Science and Technological Development of the Republic of Serbia, contract number: 451-03-68/2020-14/200045.

\section{REFERENCES}

Acosta, A., Y., Boeck G., Klimitsch, F., Schatzmayr, G., $\&$ Pasteiner, S. (2008). Aerobic stability and silage quality parameters. Journal of Animal Sciences, 86, E-suppl. 2/Dairy Science, 91, E-suppl. 1, p. 30. https://www.jtmtg.org/JAM/2008/abstracts/0027.P DF

Adamović, M. (2001). Proizvodnja silaže i senaže. [Manual]. Belgrade: Društvo poljoprivrednih inženjera i tehničara.

Adamović, M. (2019). Program istraživanja i razvoj proizvoda na bazi pirofilita u stočarstvu i veterini, skladištenju žitarica, ribarstvu i gljivarstvu [Research programme]. Federacija BiH, AD Harbi d.o.o.

Adamović, M, Lemić, J, Jovičin, M, Tomašević- Čanović, M., Jovičin, M., \& Kovačević, M. (2004). Uticaj pufera na produkciju i sastav mleka i metabolički profil krava. Biotehnologija u stočarstvu, 20 (5-6), 195-202.

Adamović, M., Milivojčević, D., Živanović, Č., BočarovStančić, A., \& Šorić, P. (2015). The quality of maize (plants and maize grain silage ensiled in polyethylene foil). Journal of Processing and Energy in Agriculture, 1-3, 58-60.

Adamović, M., \& Obradović, S. (2016). Proizvodnja i korišćenje silaže i senaže [monograph] (pp. 1-140). Novi Pazar, Serbia: State University of Novi Pazar.

Adamović, M., Sinovec, Z., Nešić, S., \& TomaševićČanović, M. (2001). Doprinos adsorbenata mikotoksina efikasnijem korišćenju stočne hrane. Efikasnost korišćenja zeolita u tehnologiji siliranja. In Proceedings of the IX Simpozijum Tehnologija stočne hrane (pp. 21-44). Zlatibor, Serbia.

Adamović, M., Stoićević, Lj., \& Jovanović, R. (1997). Doprinos siliranja korišćenju organske materije i zaštiti okoline. In Proceedings of Savetovanje
Ekotehnologija u prehrambenoj industriji $i$ biotehnologiji (pp. 233-242). Vrnjačka Banja, Serbia.

Adamović, M., \& Stojanović, M. (2019). Pirofilit (prirodni i modifikovan-oplemenjen)-funkcionalna hrana za biljke i životinje [Research report]. AD Harbi d.o.o., Sarajevo, Bosnia and Herzegovina.

Ashbell, G., \& Kashanchi, Y. (1987). In-silo losses from wheat ensiled in bunker silos in a subtropical climate. Journal of the Science of Food Agriculture, 40, 95-103.

Ashbell, G., Weinberg, Z. G., Hen, Y., \& Filya, I. (2002). The effects of temperature on the aerobic stability of wheat and corn silages. Journal of Industrial Microbiology and Biotechnology, 28, 261-263.

Bakici, Y., \& Demirel, M. (2004). Determination of qualities of corn, sorghum, sudangrass and sorghum $\mathrm{x}$ sudangrass hybrid silages. Journal of Applied Animal Research, 26, 45-48.

Bočarov-Stančić, A., Bodroža-Solarov, M., Stanković, S., Janković, S., Đisalov, J., Novaković, Ž., \& Adamović, M. (2015). Mycotoxins in cattle diet biodegradation in rumen, occurrence and prevention of mycotoxicoses. In Proceedings of the $4^{\text {th }}$ International Congress "New Perspectives and Challenges of Sustainable Livestock Production" (pp. 748-759). Belgrade, Serbia.

Borreani, G., \& Tabacco, E. (2010). The relationship of silage temperature with the microbiological status of the face of corn silage bunkers. Journal of Dairy Science, 93 (6), 2620-2629.

Borreani, G., Tabacco, E., \& Cavallarin, L. (2007). A new oxygen barrier film reduces aerobic deterioration in farm scale corn silage. Journal of Dairy Science, 90, 4701-4706.

Danner, H., Holzer, M., Mayrhuber, E., \& Braun, R. (2003). Acetic acid increases stability of silage under aerobic conditions. Applied and Environmental Microbiology, 69 (1), 562-567.

Desai, H., Biswal, N. R., \& Paria, S. (2010). Rheological behavior of pyrophyllite-water slurry in the presence of anionic, cationic, and nonionic surfactants. Industrial \& Engineering Chemistry Research, 49 (11), 5400-5406.

Drits, V. A., Derkowski, A., \& McCarty, D. K., (2011). Kinetics of thermal transformation of partially dehydroxylated pyrophyllite. American Mineralogist, 96, 1054-1069.

Đorđević, N., Adamović, M., Grubić, G., \& BočarovStančić, A. (2004). Uticaj organozeolita i uree na hemijski sastav i kvalitet silaže cele biljke kukuruza. Biotehnologija u stočarstvu, 20 (5-6), 187-194.

Đorđević, N., Grubić, G., \& Adamović, M. (2005). The influence of zeolite addition on quality of fresh lucerne silage. Acta Agriculturae Serbica, 10 (19), 25-31.

Đorđević, N., Grubić, G., Adamović, M., Nježić, D., Nježić, A., \& Stojanović, B. (2006). The influence of addition of zenural 70, urea and Min-a-Zel plus on chemical composition and quality of whole maize plant silage. Journal of Agricultural Sciences, 51 (1), 71-78.

Đorđević, N., Grubić, G., \& Jokić, Ž. (2003). Osnovi ishrane domaćih životinja - praktikum. Univerzitet u Beogradu, Beograd: Poljoprivredni fakultet.

Erdemoglu, M., Erdemoglu, S., Sayılkan, F., Akarsu, M., Sener, S, \& Sayılkanc, H. (2004). Organo- 
functional modified pyrophyllite: preparation, characterisation and $\mathrm{Pb}$ (II) ion adsorption property. Applied Clay Science, 27, 41 - 52.

Essalhi, A., Essalhi, M., Toummite, A., Mostadi, A. El., \& Raddi, Y. (2017). Mineralogical and textural arguments for a metasomatic origin of the Ougnat pyrophyllite, Eastern Anti-Atlas, Morocco. Journal of Materials and Environmental Science, 8 (1), 2232.

Grubić, G., \& Adamović, M. (2003). Ishrana visokoproizvodnih krava (p. 201). Beograd: Institut PKB Agroekonomik.

Harbinja, M., Hodžić, A., Kaljanac, A., Selman, F., Radulović, D., Andrić, Lj., Stojanović, J., \& Petrović, M. (2019). Pirofilit - mineral budućnosti za primenu u poljoprivredi [unpublished monograph]. AD Harbi, Sarajevo, Federacija BiH.

Ivetić, A., Đorđević, N., Radin, D., Stojić, P., Grubić, G., Stojanović, B. (2013). Značaj aerobne stabilnosti silirane stočne hrane. In Proceedings of XXVII Savetovanje agronoma, veterinara, tehnologa $i$ agroekonomista, 19 (3-4), pp. 47-59.

Karnwal, A., \& Bhardway, V. (2014). Bioremediation of heavy metals ( $\mathrm{Zn}$ and $\mathrm{Cr}$ ) using microbial biosurfactant. Journal of Environmental Research and Protection, 11, 29-33.

Keren, R., \& Sparks, D. L. (1994). Effect of pH and ionic strength on boron adsorption by pyrophyllite. Soil Science Society of America Journal, 58, 1095-1100.

Kim, J. H., Lee, C. G., Park, J. A., \& Kang, J. (2013). Use of pyrophyllite clay for fluoride removal from aqueous solution. Desalination and water treatment, 51 (16-18), 3408-3416.

Koljajić, V., Đorđević, N., Grubić, G., \& Adamović, M. (2003). The influence of zeolite on the quality of fresh beet pulp silages. Journal of Agricultural Sciences, 48 (1), 77-84.

Marković, J., Blagojević, M., Kostić, I., Vasić T., Anđelković S., Petrović, M., \& Štrbanović, R. (2018). Effect of bacterial inoculants application and seeding rate on common vetch-oat silage quality. Biotechnology in Animal Husbandry, 34 (2), 251-257.

Muck, R. E., Moser, L. E., \& Pitt, R. E. (2003). Postharvest factors affecting ensiling. In D. R. Buxton, R. E. Muck \& J. H. Harrison (Eds.), Silage Science and Technology (pp. 251-304). Madison, WI, USA: Crop Science Society of America.

Obradović, M. (1965). Jedinice za određivanje hranljive vrednosti hraniva i njihovo određivanje. Beograd: Jugoslovenski poljoprivredno-šumarski centar i Institut za stočarstvo.

Pahlow, G., \& Muck, R. E. (2009). Managing for improved aerobic stability. In Proceedings of the XV International Silage Conference (pp. 77-90). Madison, Wisconsin, USA.

Park, J., Kim, J. H., Lee C. G., \& Kim, S. B. (2013). Pyrophyllite clay for bacteriophage MS2 removal in the presence of fluoride. Water Science \& Technology Water Supply, 14 (3), 485.

Pravilnik. (1987). Pravilnik o metodama uzimanja uzoraka i metodama fizičkih, hemijskih i mikrobioloških analiza stočne hrane. Službeni list SFRJ, 15, methods 6 and 15 .

Sánchez-Soto, P. J., Justo, A., \& Pérez-Rodríguez, J. L. (1994). Grinding effect on kaolinite-pyrophylliteillite natural mixtures and its influence on mullite formation. Journal of Materials Science, 29 (5), 1276-1283.

United States Food and Drug Administration. (2019). Part 573 - Food additives permitted in feed and drinking water of animals. Food and Drugs, Chapter I - Food and drug administration, Department of Health and Human Services, Subchapter E-Animal drugs, feeds, and related products. US FDA, Silver Spring, MD.

https://www.accessdata.fda.gov/scripts/cdrh/cfdocs/ cfcfr/CFRSearch.cfm?fr=573.900)

Vujanac, I., Adamović, M., Šamanc, H., Petrujkić, B., \& Dimitrijević, B. (2005). Preveniranje kiselih indigestija goveda primenom mineralnih materija regulatora elektrohemijske reakcije sadržaja buraga. In Proceedings of the $7^{\text {th }}$ Clinica Veterinaria (pp. 284-288). Ohrid, Macedonia. 


\section{ИСПИТИВАЊЕ ЕФИКАСНОСТИ КОРИШКЕЊА ПИРОФИЛИТА У СИЛИРАҢУ БИЉКЕ КУКУРУЗА}

Милан Ј. Адамовић ${ }^{1}$, Мирјана Д. Стојановић ${ }^{2}$, Мухамед М. Харбиња ${ }^{3}$, Маријана Д. Масловарић ${ }^{4}$, Александра С. Бочаров-Станчић ${ }^{4 *}$, Лато Л. Пезо

\footnotetext{
${ }^{1}$ Институт за технологију нуклеарних и других минералних сировина, 11000 Београд, Бул. Франше д’ Епереа 86, Србија

${ }^{2}$ Инжењерска академија Србије, 11000 Београд, Кнеза Милоша 9/1, Србија

${ }^{3}$ АД, Харби Ltd., 71000 Сарајево, Творничка 3, Босна и Херцеговина

${ }^{4}$ Институт за примену науке у пољопривреди, 11000 Београд, Бул. деспота Стефана 68б, Србија

${ }^{5}$ Универзитет Београду, Институт за физичку хемију, 11000 Београд, Студентски трг 12/B, Србија
}

Сажетак: Циљ спроведеног испитивања био је да се утврди утицај пирофилитног шкриљца (пирофилит) са налазишта Парсовићи, Коњиц, АД Харби Ltd., Сарајево, Босна и Херцеговина на квалитет ферментације силаже, у првом реду на продукцију органских киселина (млечна, сирћетна и бутерна), затим на $\mathrm{pH}$ вредност, оцену квалитета, као и микробиолошку исправност силаже. Силажирање је обављено у пластичним посудама које су омогућиле складиштење 10 кг уситњене зелене биомасе кукуруза. Испитане дозе пирофилита су биле: $0 \%$ у контролном третману (I), a 0,5 і 1,0\% у експерименталним третманима (II і III). Гранулисани пирофилит $(100 \mu \mathrm{m})$ ручно је додат силажи. Исечена зелена маса биљке кукуруза, пореклом из FAO 600 групе хибрида, садржала је $37,17 \%$ суве материје (завршна воштана фаза) и била је компримована на исти начин код сва 3 третмана приликом пуњења посуда. Посуде за силирање су прекривене најлонском фолијом $(0,2 \mathrm{~mm})$ изнад које је постављен слој ситног песка (приближно $5 \mathrm{~cm}$ ) ради заштите силаже од сунчевих зрака. Силажа је отворена после 7 недеља и након тога су извршене органолептичке, хемијске и микробиолошке анализе.

Органолептичке особине силаже (боја и мирис) биле су боље код силажа са додатком пирофилита. Температура силажа у моменту отварања била је нижа у силажама са додатком пирофилита $\left(13,7\right.$ односно $\left.13,2^{\circ} \mathrm{C}\right)$ у односу на силажу без додатка пирофилита $\left(14,6{ }^{\circ} \mathrm{C}\right)$. На основу односа млечне, сирћетне и бутерне киселине као и $\mathrm{pH}$ вредности све три силаже оцењене су највишом класом (I). У силажи без додатка пирофилита утврђен је највећи садржај млечне киселине, док је у силажама са додатком 0,5 и 1,0\% пирофилита утврђен већи садржај сирћетне киселине, а најмањи садржај бутерне киселине (p $\leq 0.05)$. Број аеробних мезофилних бактерија, као и квасаца био је мањи у силажама са додатком 0,5 и $1,0 \%$ пирофилита што је у сагласности и са повећаним садржајем сирћетне киселине која доприноси аеробној стабилности силаже. Имајући у виду да пирофилит, поред осталог, има и способност адсорпције микотоксина (пре свега афлатоксина) и тешких метала, као и одржавања оптималне вредности $\mathrm{pH}$ у бурагу, даље изучавање оправданости коришћења пирофилита у силажи или сенажи, има своје оправдање и економски значај. Посебну пажњу треба посветити могућности његовог модификовања и обогаћивања (нпр. азотом) и подесној физичкој форми нпр. у облику гранула, које омогућују ефикаснију апликацију у практичним условима.

Кључне речи: пирофилит, силирање, биљка кукуруза

Received: 25 May 2020 / Received in revised form: 19 August 2020 / Accepted: 28 September 2020

Available online: November 2020

This is an open-access article under the CC BY license (http://creativecommons.org/licenses/by/3.0). 